\title{
A Note: De-Growth Debate and New Scientific Analysis of Economic Growth
}

\author{
Jari Kaivo-oja*, Jarmo Vehmas, Jyrki Luukkanen \\ Finland Futures Research Centre, Turku School of Economics, University of Turku, Tampere, Finland \\ Email: ${ }^{\text {jari.kaivo-oja@utu.fi }}$
}

Received 8 September 2014; revised 2 October 2014; accepted 26 October 2014

Copyright (C) 2014 by authors and Scientific Research Publishing Inc.

This work is licensed under the Creative Commons Attribution International License (CC BY). http://creativecommons.org/licenses/by/4.0/

(c) (i) Open Access

\section{Abstract}

This article is a theoretical note on de-growth debate. The article includes an analysis of economic growth and alternative growth paths. The article is focused on the concepts of de-linking, re-linking and de-growth. We connected linking analysis (de-linking and re-linking) analytically to the de-growth debate. On the basis of our framework, special cases of de-growth in the linking process relate to strong re-linking, weak re-linking and recessive de-linking. This kind of theoretical approach helps us to define the special nature of de-growth. Key finding of us is that only the de-growth case of recessive de-linking meets the condition of environmental sustainability. However, this case does not fulfil the criteria of sustainable development defined in the WCSD context. In the linking process, the WCSD conditions of sustainable development are met in the strong de-linking process only. In our analytical framework, the theoretical concepts of de-growth and sustainable development seem to conflict by definition.

\section{Keywords}

De-Growth, De-Linking, Re-Linking, Sustainable Development, Economic Growth

\section{Introduction}

The explanation of long-run economic development has always been a major issue in the economic theory. The "wealth of nations" today is the result of specific growth paths in the past. The present situation is characterized by huge international differences in living standards. Obviously there are different growth paths and dynamics of economic growth leads to different levels of sustainability. In this article we present a new scientific analysis of economic growth and associated sustainability analysis.

From the year 2008 onwards the Western countries have entered a period of prolonged economic recession.

\footnotetext{
*Corresponding author.
}

How to cite this paper: Kaivo-oja, J., Vehmas, J. and Luukkanen, J. (2014) A Note: De-Growth Debate and New Scientific Analysis of Economic Growth. Journal of Environmental Protection, 5, 1477-1481. 
Whether this is a temporary or a new permanent situation, is difficult to know. Ecological limits, exhaustion of investment outlets in mature economies, the burden of debt and geo-economic shifts point to a serious structural socio-economic crisis (see [1] [2]). For the environment, on the other hand, financial and economic crisis is not bad news [3], because less economic growth means less material consumption, less $\mathrm{CO}_{2}$ emissions, and less habitat destruction—a last late chance to stay within the safe limits of global ecosystems (see [4]-[7]).

Socially, a permanent economic recession can be a catastrophe. Growth economies do not know how to de-grow (see e.g. [8]). They may collapse, but also recovery is possible. In the current situation, deeper understanding of the nature of economic growth is very important, especially from the sustainability perspective. We should be more interested in what is happening to the relationship and links between economic growth and environmental impacts.

The aim of this theoretically oriented research note is to connect the de-growth debate to previous de-linking and re-linking analyses (see e.g. [9] [10]). Especially we want to define special cases of the linking process, which can be defined as preferred de-growth processes in the economy. In the next section we present a simple framework of de-linking and re-linking and its connection to de-growth.

\section{De-Linking, Re-Linking and De-Growth}

In the literature, linking refers to change in the relationship between environmental impacts and economic performance over time. De Bruyn and Opschoor [11] have defined five generic stages of the linking process and describe them with an N-shaped curve. Environmental Kuznets Curve (EKC) is a special case of a de-linking process where environmental impacts de-link from economic growth and can be illustrated by an inverted U-shaped curve.

De Bruyn [12] has separated theoretical concepts of weak and strong de-linking. Weak de-linking implies that the environmental intensity of GDP decreases over time. However, environmental impacts can still increase, but at a lower rate than the GDP growth. For de-linking to be called strong, environmental stress must decrease over time (ibid.).

The EKC hypothesis states that at the first stage, economic growth increases also environmental impacts of economic activities, but at a certain level of income (GDP per capita), environmental impacts start to decrease endogenously or "automatically", e.g. through positive income elasticity of environmental goods, technological development and structural shift towards less environmentally intensive economic activities such as services. The EKC literature suggests also other factors (see [13]-[19]).

However, identifying these factors and their environmental and social effects is not an easy task. The existence of an inverted U-shaped EKC per se does not verify the EKC hypothesis.

Assuming that the EKC hypothesis holds, doubts still remain whether the observed improvements can be extrapolated into the future or not. The possibilities to improve environmental efficiencies may have an upper limit. Facing these limits may force environmental impacts and GDP to link again. This prediction is called the re-linking hypothesis [11]. Like de-linking, also re-linking can be either weak or strong. Weak re-linking means that environmental intensity starts to increase, and strong re-linking requires that environmental impacts start to increase in absolute terms.

The linking process deals with changes in GDP $(\triangle \mathrm{GDP})$, change in environmental impacts $(\Delta \mathrm{ES})$ and change in the environmental intensity of GDP, $\Delta(\mathrm{ES} / \mathrm{GDP})$.

Figure 1 defines all different combinations of possible changes (see [9] for more detailed discussion). Horizontal axis in Figure 1 represents change in GDP and vertical axis represents change in environmental impacts. Environmental intensity of GDP (ES/GDP) is represented by the third axis.

All the axes in Figure 1 are relative, so they describe change from the current value of each variable only. The areas between the axes can be considered as defining six different types of the linking process, based on simultaneous changes over time in the variables $\Delta \mathrm{ES}, \Delta \mathrm{GDP}$ and $\Delta(\mathrm{ES} / \mathrm{GDP})$ from the current (reference) values.

Many de-growth thinkers and activists advocate downscaling of production and consumption. They prefer the contraction of economies as over consumption lies at the root of long term environmental and social problems. It is easier to avoid a climate change disaster with less growth [20]. But socially, lack of growth in the Western economies may be problematic or even catastrophic. Even developing countries can suffer from low level of demand in markets. Unemployment increases and debt accumulates in many economies as we have seen during the recent years of financial crisis. 


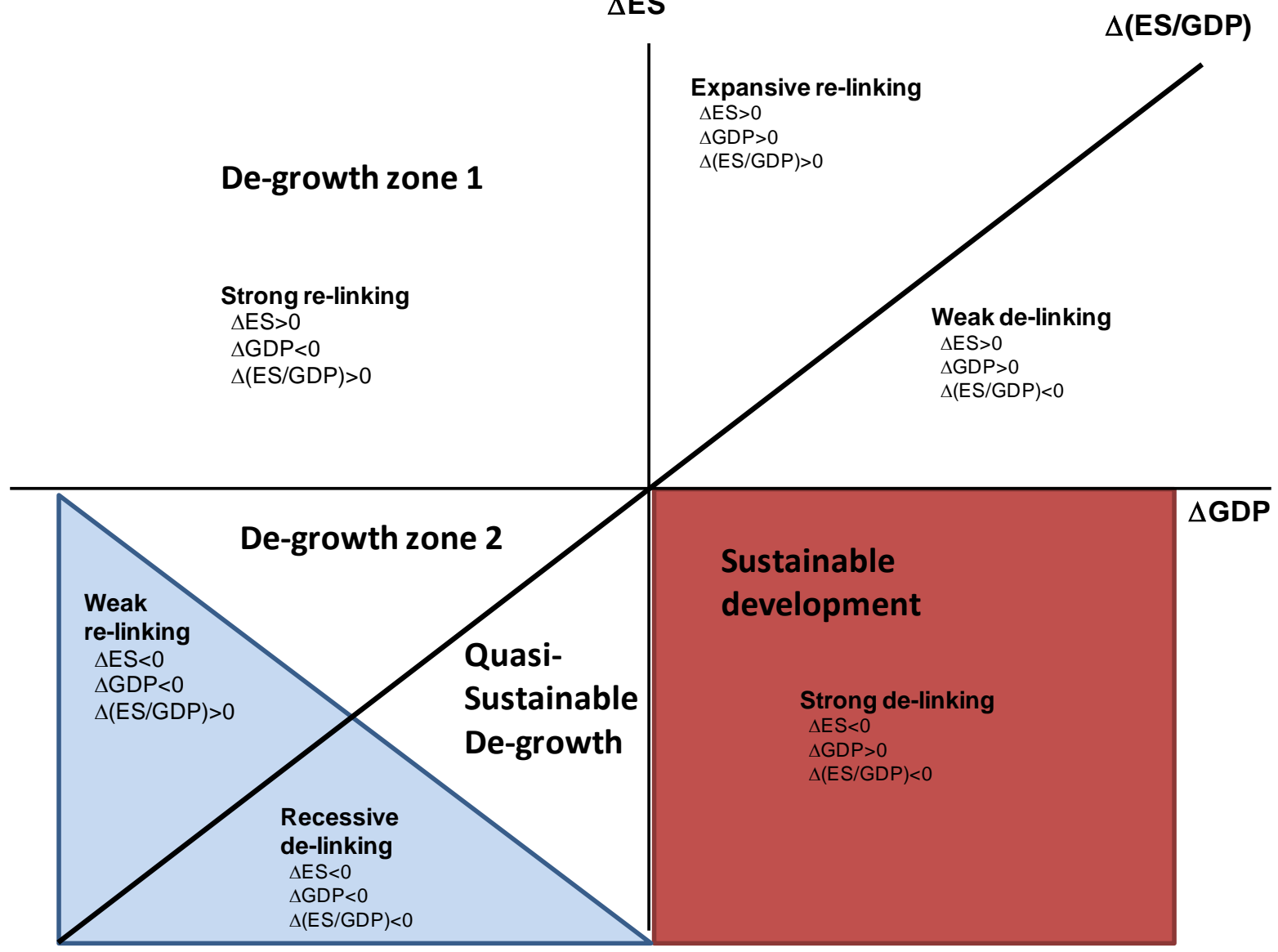

Figure 1. De-growth and degrees of the linking process.

How can economies without growth become socially sustainable and economically functional? One suggestion is to reduce working time [21]. Any de-growth strategy has challenges of its own. It can be interpreted that a de-growth strategy is an ecological strategy, which may help us in the creation of more sustainable consumption structures.

Key issue of de-growth strategies is that reducing consumption does not necessarily require decrease in individual well-being. Theoretically de-growth could include downscaling of production and consumption with simultaneously increasing human well-being and enhancing ecological conditions and equity on the planet. De-growth calls for a future where societies live within their ecological means with open, localized economies and resources more equally distributed through new forms of open society and democratic institutions. The promoters of de-growth aim to maximize happiness and well-being through non-consumptive means (see [22] [23]). They prefer shared work and consuming less while devoting more time to leisure, art, music, family, culture and community. Typically, they do not support core values of the consumption society (see e.g. [24] [25]). There is also quite a lot of criticism concerning de-growth (see e.g. [10]).

In Figure 1, de-growth refers to a situation where change in GDP over time ( $\triangle \mathrm{GDP}$ ) is negative, usually called as recession. In the linking process, de-growth can happen together with strong re-linking, weak re-linking, and recessive de-linking. It is very important to understand that de-growth can be either a re-linking or delinking type of economic process. From the perspective of environmental sustainability promoted by many de-growth advocates, only recessive de-linking meets the sustainability criterion $(\Delta \mathrm{ES}<0)$. Because of the lack of economic growth in de-growth process we use the term quasi-sustainable de-growth. This kind of de-growth process does not fulfil the conventional economic sustainability criteria of the Brundtland Commission.

On the other hand, if we take the conditions of sustainable development defined by the World Committee on Sustainable Development [26] [27] as the starting point, sustainability can only be met in the strong de-linking 
process. De-growth seems to be always in conflict with sustainable development, which indicates that generic considerations are not fruitful but a more detailed growth approach will be needed.

\section{Summary}

In this integrative research note, we have connected linking analysis (de-linking and re-linking) analytically to the de-growth debate. On the basis of our framework, special cases of de-growth in the linking process relate to strong re-linking, weak re-linking and recessive de-linking. This kind of theoretical approach helps us to define the very special nature of de-growth. There is need to analyse growth processes of regional and national economies from this novel theoretical approach.

Another important scientific task is to evaluate the conditions under which the present development will be sustainable in the future. Huge international differences in economic growth and living standards are, of course, linked to the limited supply of natural resources. Contributing to the explanation of this pervasive observation is a challenge for any modern theory of economic growth and sustainable development. The sustainability analysis framework presented in this article helps us to meet these pervasive challenges of history.

Only the de-growth case of recessive de-linking meets the condition of environmental sustainability. However, this case does not fulfil the criteria of sustainable development defined in the WCSD context. In the linking process, the WCSD conditions of sustainable development are met in the strong de-linking process only. In our analytical framework, de-growth and sustainable development seem to conflict by definition.

\section{References}

[1] Kallis, G. (2011) In Defence of Degrowth. Ecological Economics, 70, 873-880. http://dx.doi.org/10.1016/j.ecolecon.2010.12.007

[2] Wallerstein, I. (2010) Structural Crises. New Left Review, 62, 133-142.

[3] Martinez-Alier, J. (2009) Socially Sustainable Economic De-Growth. Development and Change, 40, 1099-1119. http://dx.doi.org/10.1111/j.1467-7660.2009.01618.x

[4] Kaivo-oja, J. (1999) Alternative Scenarios of Social Development: Is Analytical Sustainability Policy Analysis Possible? How? Sustainable Development, 7, 140-150. http://dx.doi.org/10.1002/(SICI)1099-1719(199908)7:3<140::AID-SD109>3.0.CO;2-I

[5] Rockström, J., Steffen, W., Noone, K., Persson, Å., Chapin, F.S., Lambin, E.F., Lenton, T.M., Scheffer, M., Folke, C., Schellnhuber, H.J., Nykvist, B., de Wit, C.A., Hughes, T., vander Leeuw, S., Rodhe, H., Sörlin, S., Snyder, P.K., Costanza, R., Svedin, U., Falkenmark, M., Karlberg, L., Corell, R.W., Fabry, V., Hansen, J., Walker, B., Liverman, D., Richardson, K., Crutzen, P. and Foley, J.A. (2009) A Safe operating Space for Humanity. Nature, 461, 472-475. http://dx.doi.org/10.1038/461472a

[6] Smith, R. (2010) Beyond Growth or Beyond Capitalism? Real World Economics Review, 53, 28-36.

[7] Kallis, G., Kerschner, C. and Martinez-Alier, J. (2012) The Economics of Degrowth. Ecological Economics, 84, 172180.

[8] Victor, P.A. (2008) Managing without Growth: Slower By Design, Not Disaster. Edward Elgar, Cheltenham, UK, Northampton, MA. http://dx.doi.org/10.4337/9781848442993

[9] Vehmas, J., Luukkanen, J. and Kaivo-oja, J. (2007) Linking Analyses and Environmental Kuznets Curves for Aggregated Material Flows in the EU. Journal of Cleaner Production, 15, 1662-1673. http://dx.doi.org/10.1016/j.jclepro.2006.08.010

[10] van den Bergh, J. (2011) Environment versus Growth. A Criticism of "Degrowth" and a Plea for A-Growth. Ecological Economics, 70, 881-890. http://dx.doi.org/10.1016/j.ecolecon.2010.09.035

[11] de Bruyn, S.M. and Opschoor, J.B. (1997) Developments in the Throughput-Income Relationship: Theoretical and Empirical Observations. Ecological Economics, 20, 255-268. http://dx.doi.org/10.1016/S0921-8009(96)00086-9

[12] de Bruyn, S.M. (2000) Economic Growth and the Environment. Kluwer Academic Publishers, Dordrect.

[13] Magnani, E. (2001) The Environmental Kuznets Curve: Development Path or Policy Result? Environmental Modelling \& Software, 16, 157-165. http://dx.doi.org/10.1016/S1364-8152(00)00079-7

[14] Panayotou, T. (1993) Empirical Test and Policy Analysis of Environmental Degradation at Different Stages of Economic Development. World Employment Research Programme, Working Paper, International Labour Office, Geneva.

[15] Grossman, G.M. and Krueger, A.B. (1995) Economic Growth and the Environment. Quarterly Journal of Economics, 110, 353-377. http://dx.doi.org/10.2307/2118443 
[16] Ekins, P. (1997) The Kuznets Curve for the Environment and Economic Growth: Examining the Evidence. Environment and Planning A, 29, 805-830. http://dx.doi.org/10.1068/a290805

[17] Rothman, D.S. and de Bruyn, S. (1998) Probing into the Environmental Kuznets Curve Hypothesis. Ecological Economics, 25, 143-145.

[18] Borghesi, S. (1999) The Environmental Kuznets Curve: A Survey of Literature. European University Institute, Florence.

[19] Seppälä, T., Haukioja, T. and Kaivo-oja, J. (2001) The EKC Hypothesis Does Not Hold for Direct Material Flows: Environmental Kuznets Curve Hypothesis Tests for Direct Material Flows in 5 Industrial Countries. Population and Environment: A Journal of Interdisciplinary Studies, 23, 217-238. http://dx.doi.org/10.1023/A:1012831804794

[20] D’Alisa, G. and Cattaneo, C. (2013) Household Work and Energy Consumption: A Degrowth Perspective. Catalonia’s Case Study. Journal of Cleaner Production, 38, 71-79. http://dx.doi.org/10.1016/j.jclepro.2011.11.058

[21] Victor, P.A. (2012) Growth, Degrowth and Climate Change: A Scenario Analysis. Ecological Economics, 84, $206-212$. http://dx.doi.org/10.1016/j.ecolecon.2011.04.013

[22] Sekulova, F., Kallis, G., Rodríguez-Labajos, B. and Schneider, F. (2013) Degrowth: From Theory to Practice. Journal of Cleaner Production, 38, 1-6. http://dx.doi.org/10.1016/j.jclepro.2012.06.022

[23] Lorek, S. and Fuchs, D. (2013) Strong Sustainable Consumption Governance-Precondition for a Degrowth Path? Journal of Cleaner Production, 38, 36-43. http://dx.doi.org/10.1016/j.jclepro.2011.08.008

[24] Latouche, S. (2009) Farewell to Growth. Polity Press, Cambridge.

[25] Nørgård, J.S. (2013) Happy Degrowth through More Amateur Economy. Journal of Cleaner Production, 38, 61-70. http://dx.doi.org/10.1016/j.jclepro.2011.12.006

[26] Bruntland, G. (1987) Our Common Future: The World Commission on Environment and Development. Oxford University, Oxford.

[27] Brundtland, G.H. (1987) What Is Sustainable Development? Fourteen Case Studies Prepared by African and Asian Journalists. In Omoro, B., et al., Eds., Towards Sustainable Development, Panos Publications Ltd., Panos Books, London, vii-ix. 
Scientific Research Publishing (SCIRP) is one of the largest Open Access journal publishers. It is currently publishing more than 200 open access, online, peer-reviewed journals covering a wide range of academic disciplines. SCIRP serves the worldwide academic communities and contributes to the progress and application of science with its publication.

Other selected journals from SCIRP are listed as below. Submit your manuscript to us via either submit@scirp.org or Online Submission Portal.
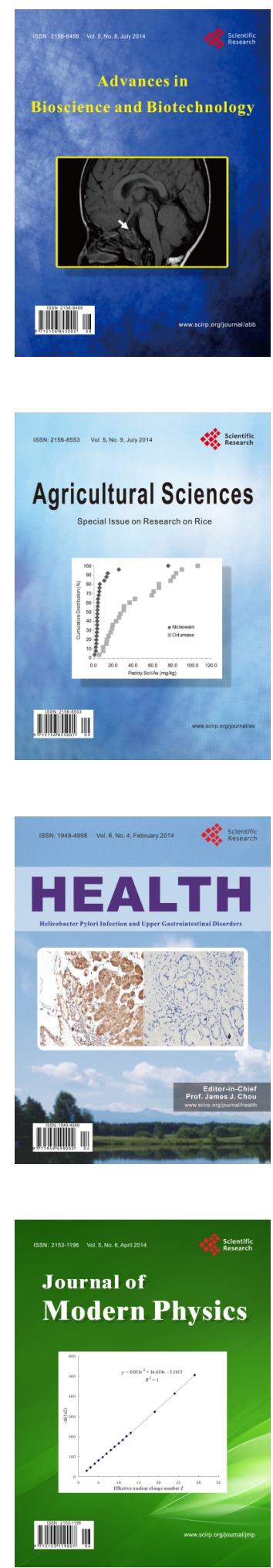
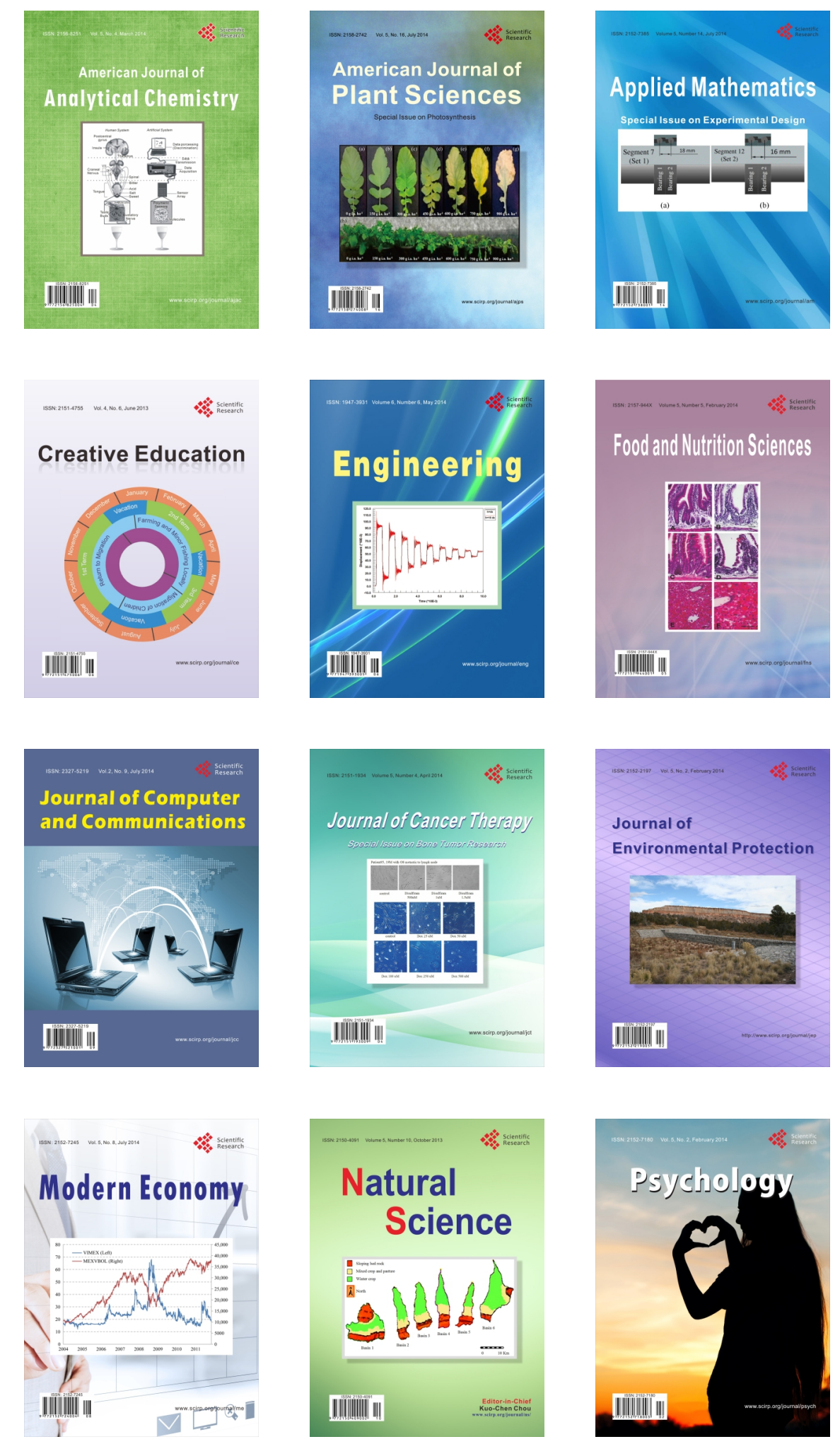